\title{
Meta-Regulation of Private Standards: The Role of Regional and International Organizations in Comparison with the WTO - ERRATUM
}

(First published online 24 February 2020)

Doi: 10.1017/S1474745619000429, Published online by Cambridge University Press 14 February 2020

The above article was published with Yoshiko Naiki's name given as Yoshiko Ynaiki. Cambridge University Press apologises for this error and it has since been rectified.

\section{Reference}

Naiki, Y. (n.d.). Meta-Regulation of Private Standards: The Role of Regional and International Organizations in Comparison with the WTO. World Trade Review, 1-24. doi:10.1017/S1474745619000429

Cite this article: (2021). Meta-Regulation of Private Standards: The Role of Regional and International Organizations in Comparison with the WTO - ERRATUM. World Trade Review 20, 135. https://doi.org/10.1017/S1474745620000154

(c) The Author(s), 2020. Published by Cambridge University Press 